\title{
Insulin regulation of gene expression and concentrations of white adipose tissue-derived proteins in vivo in healthy men: relation to adiponutrin
}

\author{
May Faraj, Genevieve Beauregard, Emmanuelle Loizon ${ }^{1}$, Marthe Moldes ${ }^{2,3,4,5}$, Karine Clément ${ }^{6}$, \\ Youssef Tahiri ${ }^{7}$, Katherine Cianflone ${ }^{\mathbf{3}}$, Hubert Vidal ${ }^{\mathbf{1}}$ and Rémi Rabasa-Lhoret
}

Laboratoire des dysfonctions Métabolique, Département de Nutrition, Faculté de Médicine, Université de Montréal, 2405 Chemin Côte Ste-Catherine, Montréal, Québec, Canada H3T 1A8

${ }^{1}$ Inserm U449/INRA U1235, IFR 62, René Laennec Faculty of Medicine, Lyon, France

${ }^{2}$ Institut Cochin, Département d'Endocrinologie, Métabolisme et Cancer, Paris, F-75014 France

${ }^{3}$ Inserm, U567, Paris, F-75014 France

${ }^{4}$ CNRS, UMR 8104, Paris, F-75014 France

${ }^{5}$ Faculté de Médecine René Descartes, Université Paris Descartes, UMR-S 8104, Paris, F-75014 France

${ }^{6}$ Nutrition Department, Inserm 'Avenir' Paris 6 University, EA 3502, AP/HP, Hôtel-Dieu, Paris, France

${ }^{7}$ Mike Rosenbloom Laboratory for Cardiovascular Research, McGill University Health Center, 687 Pine Ave West, Montréal, Québec, Canada

${ }^{8}$ Centre de Recherche Hôpital Laval, Université Laval, Québec, Canada

(Requests for offprints should be addressed to M Faraj; Email: may.faraj@umontreal.ca)

\begin{abstract}
Adiponutrin is a newly described white adipose tissue (WAT)derived protein whose function and regulation remain widely unclear in humans though it is suggested to be related to insulin sensitivity. Recently, we found that adiponutrin expression is reduced in type 2 diabetic subjects in basal and insulinstimulated states. To examine adiponutrin regulation by the insulin pathway in relation to other WAT-related proteins with well-known relation to insulin signaling and action, we examined in healthy young men (1) the association of adiponutrin with $\mathrm{p} 85 \alpha \mathrm{PI} 3 \mathrm{~K}$ and HKII, leptin, adiponectin, and acylation-stimulating protein (ASP) and (2) the regulation of adiponutrin and WAT-derived proteins by 3 -h hyperinsulinemic euglycemic clamp (HIEG). At baseline $(N=20)$, adiponutrin expressions were positively correlated with those of $\mathrm{p} 85 \alpha$ PI3K $(R=0 \cdot 54, P=0 \cdot 017)$, HKII $(R=0 \cdot 58$, $P=0 \cdot 010)$, and serum leptin $(R=0.51, P=0.036)$, but not with any other parameter measured including insulin sensitivity. Hyperinsulinemia ( $N=10,+2365 \%$ above baseline)
\end{abstract}

significantly increased the expression of adiponutrin $(+770 \%$, $P=0 \cdot 002), \mathrm{p} 85 \alpha$ PI3K $(+150 \%, P=0 \cdot 033)$, HKII $(+147 \%$, $P=0.007)$, and serum leptin $(+11 \%, P=0.031)$, while it decreased serum adiponectin $(-15 \%, P=0 \cdot 001)$. In the insulin-stimulated state, adiponutrin mRNA expression levels correlated with basal p85 $\alpha$ PI3K $(R=0 \cdot 76, P=0 \cdot 018)$ and HKII $(R=0 \cdot 86, P=0 \cdot 003)$ expression levels, with percentage increase in insulin $(R=0.73, P=0.040)$, and with insulinstimulated state HKII $(R=0 \cdot 82, P=0 \cdot 007)$, leptin $(R=0 \cdot 84$, $P=0.005)$, and adiponectin $(R=0.85, P=0 \cdot 004) \mathrm{mRNA}$ levels. In healthy young men, adiponutrin expression is unregulated by hyperinsulinemia and is related to basal and/or insulin-stimulated p85 $\alpha$ PI3K, HKII, adiponectin, and leptin expression levels. We hypothesize that insulin-mediated regulation of adiponutrin expression is under the PI3K pathway. The relevance of the present findings to reduced adiponutrin expression in type 2 diabetes is discussed.

Journal of Endocrinology (2006) 191, 427-435

\section{Introduction}

Adiponutrin is a newly described non-secreted protein mainly expressed in brown and white adipose tissues (WAT; Baulande et al. 2001, Kershaw et al. 2006). To date, the physiological function of adiponutrin is unknown though it is suggested that adiponutrin may facilitate lipid storage in WAT (Jenkins et al. 2004, Lake et al. 2005, Kershaw et al. 2006). Similarly, the physiological regulation of adiponutrin expression is still being explored but several lines of evidence, mainly in rodents, suggest that adiponutrin may be regulated by energy balances and particularly by insulin.

In vitro, adiponutrin expression increases with differentiation of murine pre-adipocytes and is induced by glucose and insulin treatments of these cells (Baulande et al. 2001, Kershaw et al. 2006). Accordingly, adiponutrin expression in rodent's WAT decreases with fasting (Baulande et al. 2001, Bertile \& Raclot 2004, Wiesner et al. 2004, Kershaw et al. 
2006) and increases with refeeding (Baulande et al. 2001, Kershaw et al. 2006) and with the ingestion of highcarbohydrate and high-protein meals (Polson \& Thompson 2003, 2004). Moreover, WAT adiponutrin expression is decreased in two mice models of altered insulin action: the insulin-receptor knockout mice and the insulin-deficient mice (streptozotocin-induced diabetes), a defect that is corrected upon insulin replacement in this later mouse model (Kershaw et al. 2006). Finally, as adiponutrin expression is increased in obese $f a / f a$ Zucker rats (having increased $o b$ gene expression) (Guerre-Millo 1997, Baulande et al. 2001), while it is reduced in leptin-deficient obese $o b / o b$ mice (Lake et al. 2005), leptin pathway may be implicated in the regulation of adiponutrin expression.

Little is known about adiponutrin regulation in human. To date only two studies were reported, results of which are partially inconsistent with each other and murine data. S.c. WAT adiponutrin expression was not increased in obese subjects and was associated with insulin sensitivity in one study (Liu et al. 2004) but not in the other (where insulin sensitivity was associated with adiponutrin expression in visceral WAT only; Johansson et al. 2006). However, both human studies suggest that adiponutrin expression may be regulated by insulin and glucose. In one study, adiponutrin expression in WAT was decreased after energy restriction and was increased upon refeeding (Liu et al. 2004) and in the other, adiponutrin expression in cultured human adipocytes was induced by insulin in a glucose-dependent manner (Johansson et al. 2006).

Clearly much remains to be explored regarding the regulation of adiponutrin in human, particularly given the possible role of adiponutrin in insulin sensitivity. Recently, we examined the regulation of adiponutrin expression by hyperinsulinemia in type 2 diabetic obese subjects. Despite their obese state and the origin of adiponutrin being WAT, fasting adiponutrin expression as well as insulinstimulated increase in adiponutrin expression were reduced in obese diabetic subjects when compared with controls (Moldes et al. 2006).

Insulin sensitivity as well as the regulation of many WATderived proteins involved in insulin action are defective in type 2 diabetes and may affect the regulation of adiponutrin expression. To better understand the in vivo regulation of adiponutrin by the insulin pathway and explain its reduced expression in type 2 diabetes, we explored (1) the association of adiponutrin with insulin sensitivity and WAT-derived proteins of known relation to insulin signaling and action and (2) the concomitant regulation of adiponutrin with the WATderived proteins by insulin infusion. The WAT-derived proteins examined were hexokinase II (HK II), the regulatory subunit $\mathrm{p} 85 \alpha$ of phosphatidylinositol-3 kinase (PI3K), leptin, adiponectin, and acylation-stimulating protein (ASP). These proteins have been well characterized and described in relation to insulin action in healthy and in reduced insulin sensitivity state-like type 2 diabetes (Lefai et al. 2001, Saltiel \& Kahn 2001, Faraj et al. 2004).

\section{Materials and Methods}

Subjects and study design

Twenty lean, healthy Caucasian young men participated in the study. Subjects underwent routine medical examination and biological testing. None had familial or personal history of diabetes, obesity, dyslipidemia, or hypertension or was on any medication. All subjects were sedentary, having $<2$ h-structured exercise per week, and were instructed not to engage in any exercise for the previous $48 \mathrm{~h}$ before the study. The study was conducted after $12 \mathrm{~h}$ fast. All subjects gave written consent after being informed of the nature, purpose, and possible risks of the study. The experimental protocol was approved by the ethics committee of the University of Montreal.

\section{Analytical procedures}

Hyperinsulinemic euglycemic clamp (HIEG) technique To examine the effect of hyperinsulinemia alone on adiponutrin expression in WAT in vivo, ten men underwent a 3-h HIEG clamp where hyperinsulinemia was coupled to euglycemia as previously described (DeFronzo et al. 1979). Briefly, plasma insulin was elevated to a plateau concentration using primed-constant exogenous insulin infusion at $75 \mathrm{mU} / \mathrm{m}^{2}$ per min. Plasma glucose was maintained at fasting levels using 20\% dextrose infusion adjusted every 5-10 min according to repeated plasma glucose measurements. Insulin sensitivity measured by the clamp $\left(M_{\text {clamp }}\right)$ represents glucose infusion rate at the last $30 \mathrm{~min}$ of the clamp at the steady state and is expressed as $\mathrm{mg} / \mathrm{kg}$ per min (DeFronzo et al. 1979, Karelis et al. 2005). Insulin-stimulated data represent data analyzed at the last $30 \mathrm{~min}$ of the clamp.

Analysis of serum parameters Fasting serum glucose concentrations were measured with a glucose analyzer (Beckman Glucose analyzer, Mississauga, ON, Canada). Serum triglyceride (TG) and total cholesterol were measured by an automated analyzer (Beckman-Coulter, Brea, CA, USA). Serum insulin, adiponectin, and leptin levels were measured in duplicate with a commercial RIA kit (Linco Research, St Charles, MO, USA) procedure using ${ }^{125}$ I-labeled bioactive human insulin, adiponectin, and leptin respectively as tracers and a rabbit polyclonal antibody raised against full-length peptides. Serum ASP was assayed by an in-house enzyme-linked immunosorbant assay using a monoclonal antibody as capture antibody and a polyclonal antibody as detecting antibody as described previously in detail (Maslowska et al. 1999). Serum leptin, adiponectin, and ASP were not measured for three subjects for lack of sufficient serum samples. Insulin sensitivity in the fasting state was calculated using quantitative insulin sensitivity check index (QUICKI) as $1 /\left(\log _{10}\right.$ glucose $+\log _{10}$ insulin), where glucose is in $\mathrm{mg} / \mathrm{dl}$ and insulin is in $\mu \mathrm{U} / \mathrm{ml}$ (Rabasa-Lhoret et al. 2003). 
White adipose tissue biopsy S.c. abdominal WAT samples at the periumbilical level were obtained as previously described by needle biopsy under local anesthesia (Xylocaine $20 \mathrm{mg} / \mathrm{ml}$, AstraZeneca; Vidal et al. 1996). Basal tissue samples were collected $1 \mathrm{~h}$ before the initiation of the clamp. Insulin-stimulated tissue samples were collected at the end of the $3 \mathrm{~h}$ clamp during which insulin infusion rate was maintained at $75 \mathrm{mU} / \mathrm{m}^{2}$ per $\min$ and plasma glucose concentration was maintained at fasting levels. Adipose tissues biopsies were immediately frozen in liquid nitrogen and stored at $-80{ }^{\circ} \mathrm{C}$ for extraction of mRNA later.

\section{Analysis of white adipose tissue mRNA expression} levels The WAT mRNA expression levels of adiponutrin, leptin, adiponectin, complement protein C3 (ASP precursor), p $85 \alpha$ PI3K, and HKII were measured in the basal and the insulin-stimulated states. The total RNA was extracted from frozen WAT samples using the RNeasy Total RNA Minikit (Qiagen). First-strand cDNAs were synthesized from $250 \mathrm{ng}$ total RNA in the presence of $100 \mathrm{U}$ Superscript II (Invitrogen) using both random hexamers and oligo (dT) primers (Promega). Real-time PCR was performed using a LightCycler (Roche Diagnostics) in a final volume of $20 \mu \mathrm{l}$ containing $5 \mu \mathrm{l}$ of a 100 -fold dilution of the reverse transcriptase (RT) reaction and $15 \mu \mathrm{l}$ reaction buffer from the FastStart DNA Master SYBR Green kit (Roche Diagnostics) with $3 \mathrm{mM} \mathrm{MgCl} 2$ and the specific primers. After amplification, melting curve analysis was performed to verify the specificity of the reactions. For quantification, a standard curve was systematically generated with six different amounts (150-30000 molecules/tube) of cDNA of the human target mRNA cloned in the pGEM plasmid (Promega). Analysis was performed using the LightCycler software (Roche Diagnostics). Gene-specific primers were designed to hybridize on different exons of the target human mRNA sequences accessible in the GenBank database.

The sequence of adiponutrin forward primer was $5^{\prime}$-GATGGAGGAGTGAGTGACAA- $3^{\prime}$ and the reverse primer was $5^{\prime}$-CTGAATGCATCCAAATATCC- $3^{\prime}$. The sequence of leptin forward primer was $5^{\prime}$-CAC-CAGGAT-CAA-TGA-CAT-TTC- $3^{\prime}$ and the reverse primer was 5'-TGC-CAG-TGT-CTG-GTC-CAT-CTT-G $3^{\prime}$. The sequence of adiponectin forward primer was $5^{\prime}$-AGGCCG-TGA-TGG-CAG-AGA-TG-3' ${ }^{\prime}$ and the reverse primer was 5'-CTT-CTC-CAG-GTT-CTC-CTT-TCCTGC- $3^{\prime}$. The sequence for C3 forward primer was $5^{\prime}$-GGA-TGA-GGA-CAT-CAT-TGC-AG-3' and the reverse primer was $5^{\prime}$-GGC-TCT-TTC-AAG-TCC-TCAAC- $3^{\prime}$. The RT-quantitative PCR assays of these adipokines have been validated previously in human WAT for leptin mRNA (Vidal et al. 1996), adiponectin mRNA (Tan et al. 2005), and C3 mRNA (Dusserre et al. 2000). For HKII and p $85 \alpha$ PI3K mRNA, the primers used for the RT-quantitative PCR have been published (Ducluzeau et al. 2001, Lefai et al. 2001). The expression levels of target genes were normalized according to a reference gene hypoxanthine phosphoribosyltransferase (HPRT). The sequence of HPRT forward primer was $5^{\prime}$-TTG-CTG-ACC-TGC-TGG-ATT-AC- $3^{\prime}$ and the reverse primer was 5'-AGT-TGA-GAG-ATC-ATC-TCC-AC-3'.

Statistical analysis Data are expressed as mean \pm s.D. The correlation was analyzed by Pearson Product Moment correlation. In the correlation analysis with adiponutrin, one data point of high adiponutrin mRNA expression level was eliminated from both basal and insulin-stimulated states as they presented outliers/influential data that we believe created many false positives. The differences between subjects who did or did not undergo the HIEG clamp were examined with a two-tailed $t$-test, while the effect of insulin on the various measured serum and WAT parameters were analyzed by twotailed paired $t$-test. Statistical analysis was performed using SigmaStat (Jandel, San Rafael, CA, USA) with significance set at $P \leq 0 \cdot 05$.

\section{Results}

\section{Basal state}

Basal anthropometric and metabolic characteristics of the 20 healthy, lean young men are presented in Table 1. As presented, adiponutrin is a relatively scarce protein as its fasting mRNA expression level was the least among the examined WAT-derived proteins, while adiponectin expression was the most abundant. At baseline, adiponutrin mRNA expression was positively correlated with the

Table 1 Basal anthropometric and metabolic characteristics of the 20 lean young men

$\begin{array}{lcc}\text { Basal characteristics }(n=20) & & \\ \text { Age (years) } & 23 \cdot 1 \pm 2 \cdot 4 & 20 \cdot 0-28 \cdot 0 \\ \text { Weight }(\mathrm{kg}) & 69 \cdot 0 \pm 6 \cdot 7 & 61 \cdot 0-79 \cdot 9 \\ \text { BMI }\left(\mathrm{kg} / \mathrm{m}^{2}\right) & 22 \cdot 3 \pm 1 \cdot 5 & 19 \cdot 8-24 \cdot 1 \\ \text { Serum concentrations } & & \\ \text { Glucose }(\mathrm{mM}) & 5 \cdot 0 \pm 0 \cdot 4 & 4 \cdot 2-5 \cdot 4 \\ \text { Insulin }(\mathrm{pM}) & 66 \cdot 9 \pm 30 \cdot 6 & 16 \cdot 5-159 \cdot 2 \\ \text { QUICKI } & 0 \cdot 35 \pm 0 \cdot 03 & 0 \cdot 30-0 \cdot 44 \\ \text { Total cholesterol }(\mathrm{mM}) & 4 \cdot 0 \pm 0 \cdot 8 & 2 \cdot 6-5 \cdot 1 \\ \text { TG }(\mathrm{mM}) & 1 \cdot 1 \pm 0 \cdot 4 & 0 \cdot 6-2 \cdot 1 \\ \text { Leptin }(\mathrm{ng} / \mathrm{ml}) & 2 \cdot 8 \pm 2 \cdot 2 & 0 \cdot 9-8 \cdot 8 \\ \text { Adiponectin }(\mu \mathrm{gg} / \mathrm{ml}) & 9 \cdot 6 \pm 3 \cdot 7 & 5 \cdot 2-20 \cdot 6 \\ \text { ASP }(\mathrm{nM}) & 25 \cdot 1 \pm 9 \cdot 6 & 8 \cdot 9-38 \cdot 2 \\ \text { WAT mRNA expression levels } & & \\ \text { HPRT } & 1 \cdot 6 \pm 0 \cdot 7 & 0 \cdot 5-3 \cdot 2 \\ \text { Adiponutrin/HPRT } & 0 \cdot 3 \pm 0 \cdot 2 & 0 \cdot 1-1 \cdot 1 \\ \text { Leptin/HPRT } & 13 \cdot 6 \pm 11 \cdot 4 & 4 \cdot 4-24 \cdot 3 \\ \text { Adiponectin/HPRT } & 83 \cdot 4 \pm 43 \cdot 6 & 28 \cdot 6-191 \cdot 2 \\ \text { C3/HPRT } & 13 \cdot 7 \pm 4 \cdot 7 & 4 \cdot 4-24 \cdot 3 \\ \text { P85 } \alpha \text { PI3K/HPRT } & 16 \cdot 7 \pm 14 \cdot 6 & 4 \cdot 7-65 \cdot 5 \\ \text { HKII/HPRT } & 20 \cdot 9 \pm 17 \cdot 9 & 4 \cdot 9-75 \cdot 1 \\ & \end{array}$

$n=20$ for all presented parameters except serum leptin, adiponectin, and ASP $(n=17)$. 


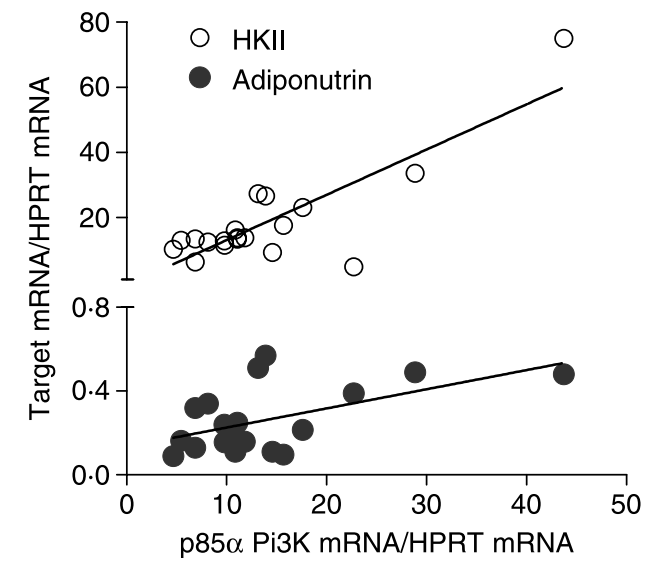

Figure 1 Pearson correlation of WAT mRNA expression levels of p85 $\alpha \mathrm{PI} 3 \mathrm{~K}$ to those of adiponutrin $(R=0 \cdot 54, P=0 \cdot 017)$ and HKII $(R=0.58, P=0.010)$ in healthy, lean young men at baseline.

mRNA expression levels of p85 $\alpha$ PI3K $(R=0.54$, $P=0 \cdot 017$; Fig. 1) and HKII $(R=0.58, P=0 \cdot 010)$, and with serum leptin $(R=0.51, P=0.036)$. There was no correlation between basal adiponutrin mRNA with any other WAT-derived protein or with age, weight, body mass index (BMI), serum lipids, insulin, glucose, or insulin sensitivity (QUICKI).

To better understand the network of WAT signals from which adiponutrin is derived, we also examined the interaction of the measured WAT-derived proteins with each other. Serum adiponectin correlated with both leptin mRNA $(R=0.66$, $P=0.004)$ and leptin concentration $(R=0.57, P=0 \cdot 016)$. The mRNA expression levels of $\mathrm{p} 85 \alpha$ PI3K correlated with leptin concentration $(R=0.56, P=0 \cdot 019)$, but not with leptin
mRNA or adiponectin and ASP concentration or mRNA. Moreover, the expression level of $\mathrm{p} 85 \alpha \mathrm{PI} 3 \mathrm{~K}$ mRNA correlated negatively with insulin $(R=-0 \cdot 51, P=0 \cdot 021)$ and positively with insulin sensitivity (QUICKI: $R=0.73, P<0.001$ ), a pattern similar to that of HKII (insulin: $R=-0 \cdot 47, P=0 \cdot 038$ and QUICKI: $R=0 \cdot 62, P=0 \cdot 004)$. The expression levels of HKII $m R N A$ and p $85 \alpha$ PI3K mRNA were also highly correlated $(R=0 \cdot 86, P<0 \cdot 0001$; Fig. 1$)$. Similar to that with adiponutrin, basal insulin or QUICKI did not correlate with leptin, adiponectin, or C3 mRNA expression levels.

\section{Insulin-stimulated state}

Out of the 20 subjects examined in the basal state, ten underwent HIEG clamps. There was no difference in all measured characteristics between the subjects who did versus those who did not do the HIEG clamp except for lower TG and ASP concentrations in the clamp subjects (clamp subjects $\mathrm{TG}=0.93 \pm 0.19 \mathrm{mM}$ versus non-clamp subjects $\mathrm{TG}=1 \cdot 33 \pm 0.43 \mathrm{mM}$ and clamp subjects $\mathrm{ASP}=16 \cdot 34 \pm$ $7 \cdot 86 \mathrm{nM}$ versus non-clamp subjects $\mathrm{ASP}=30 \cdot 42 \pm 5 \cdot 98 \mathrm{nM}$, $P<0.05$ for TG and ASP).

The effect of HIEG clamp on the expression levels and the serum concentrations of the WAT-derived proteins examined in ten lean, healthy men is presented in Table 2 and Fig. 2. Considering the range of fasting plasma insulin in healthy subjects which is 36-179 pM (Pagana \& Pagana 1997), the increase in serum insulin with the HIEG clamp was within physiological post-prandial concentrations (five to six times higher than that during fasting; English et al. 2003). The expression levels of the gene of reference HPRT were not affected by the HIEG clamp (Table 2). Hyperinsulinemia significantly increased serum concentrations of leptin and decreased that of adiponectin (Table 2), while it had no effect

Table 2 Effect of the HIEG clamp on the serum concentrations and mRNA expression levels of measured WAT-derived proteins in ten lean young men

\begin{tabular}{|c|c|c|c|c|}
\hline & Basal & Insulin stimulated & Percentage change & $P$ value \\
\hline \multicolumn{5}{|l|}{ Variables $(n=10)$} \\
\hline$M_{\text {clamp }}(\mathrm{mg}$ glucose $/ \mathrm{kg} / \mathrm{min})$ & - & $11 \cdot 8 \pm 1 \cdot 8$ & - & - \\
\hline \multicolumn{5}{|l|}{ Serum concentrations } \\
\hline Glucose $(\mathrm{mM})$ & $5 \cdot 0 \pm 0 \cdot 6$ & $5 \cdot 2 \pm 0 \cdot 4$ & $5 \cdot 7$ & $0 \cdot 374$ \\
\hline Insulin (pM) & $67 \cdot 5 \pm 40 \cdot 7$ & $1102 \cdot 1 \pm 177 \cdot 1$ & $2364 \cdot 6$ & $<0.001$ \\
\hline Leptin (ng/ml) & $3 \cdot 8 \pm 2 \cdot 9$ & $4 \cdot 2 \pm 3 \cdot 2$ & $10 \cdot 8$ & 0.031 \\
\hline Adiponectin $(\mu \mathrm{g} / \mathrm{ml})$ & $11 \cdot 6 \pm 4 \cdot 8$ & $10 \cdot 0 \pm 4 \cdot 5$ & $-15 \cdot 0$ & $0 \cdot 001$ \\
\hline $\operatorname{ASP}(n M)$ & $16 \cdot 3 \pm 7 \cdot 9$ & $13 \cdot 5 \pm 13 \cdot 5$ & $-15 \cdot 0$ & $0 \cdot 304$ \\
\hline \multicolumn{5}{|l|}{ WAT mRNA expression levels } \\
\hline HPRT & $1 \cdot 9 \pm 0 \cdot 7$ & $2 \cdot 1 \pm 1 \cdot 1$ & $12 \cdot 7$ & $0 \cdot 327$ \\
\hline Adiponutrin/HPRT & $0 \cdot 3 \pm 0 \cdot 3$ & $1 \cdot 9 \pm 1 \cdot 2$ & $789 \cdot 7$ & $0 \cdot 002$ \\
\hline Leptin/HPRT & $16 \cdot 9 \pm 13 \cdot 1$ & $20 \cdot 6 \pm 14 \cdot 7$ & $48 \cdot 3$ & $0 \cdot 145$ \\
\hline Adiponectin/HPRT & $98 \cdot 8 \pm 47 \cdot 8$ & $102 \cdot 9 \pm 54 \cdot 9$ & $6 \cdot 3$ & $0 \cdot 744$ \\
\hline C3/HPRT & $12 \cdot 8 \pm 3 \cdot 7$ & $13 \cdot 7 \pm 4 \cdot 2$ & $6 \cdot 4$ & $0 \cdot 086$ \\
\hline p85 $\alpha \mathrm{PI} 3 \mathrm{~K} / \mathrm{HPRT}$ & $20 \cdot 3 \pm 17 \cdot 2$ & $39 \cdot 1 \pm 24 \cdot 5$ & $150 \cdot 2$ & 0.033 \\
\hline HKII/HPRT & $20 \cdot 2 \pm 16 \cdot 8$ & $41 \cdot 8 \pm 23 \cdot 8$ & $146 \cdot 7$ & 0.007 \\
\hline
\end{tabular}

$n=10$ for all presented parameters except serum leptin, adiponectin, and $\operatorname{ASP}(n=7)$. 

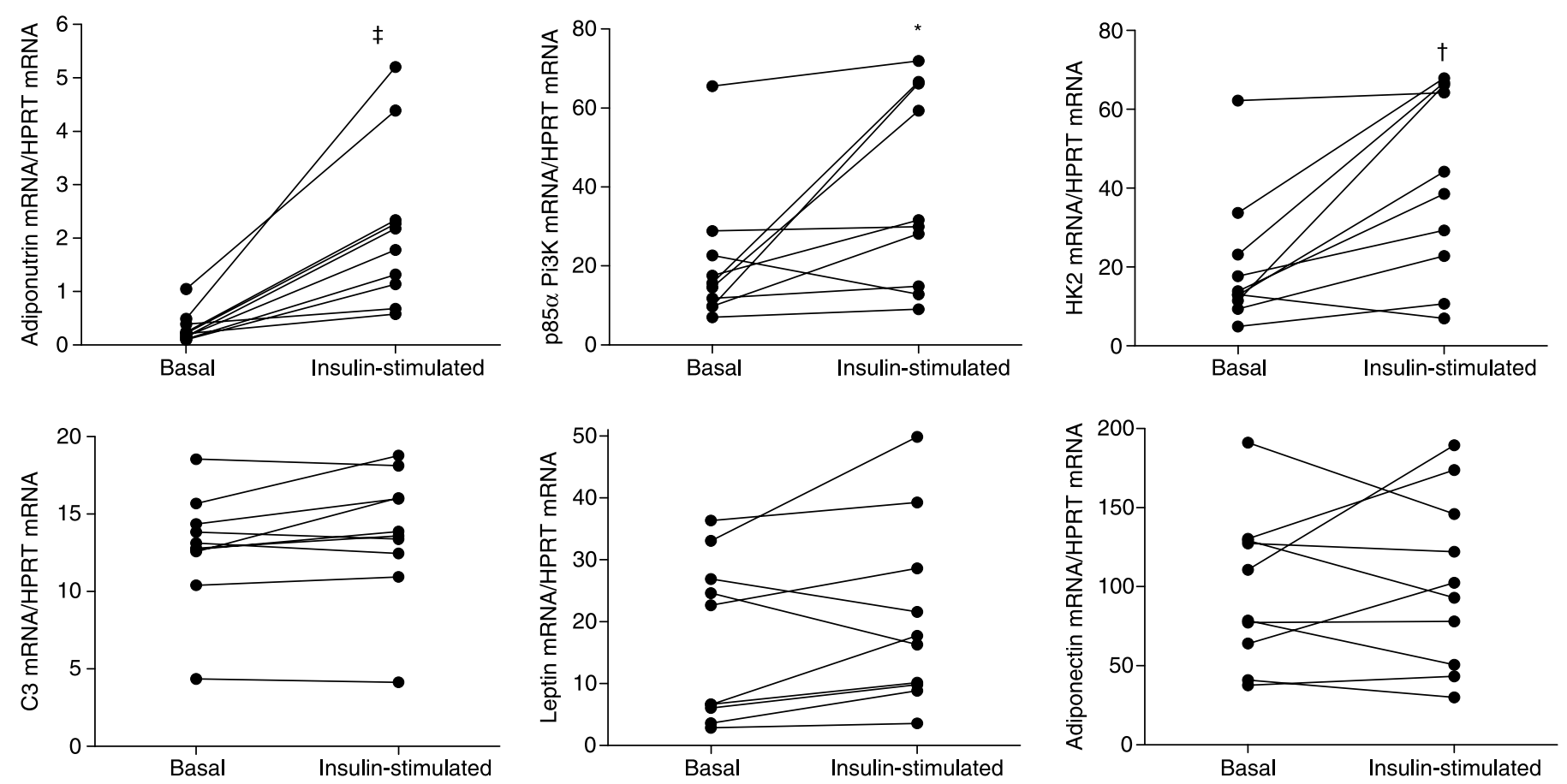

Figure 2 The expression levels of WAT-derived proteins at the basal and the insulin-stimulated states induced by HIEG clamps in healthy, lean young men. ${ }^{*} P<0 \cdot 05,{ }^{+} P<0 \cdot 01$, and ${ }^{\ddagger} P<0 \cdot 001$. 
on the mRNA expression levels of these hormones (which may indicate an insulin effect at the post-transcription level only). In addition, hyperinsulinemia significantly increased the mRNA expression levels of adiponutrin, p85 $\alpha$ PI3K, and HKII. There was no effect of $3 \mathrm{~h}$ hyperinsulinemia on the concentration of ASP or the expression levels of its precursor protein C3.

Insulin-stimulated adiponutrin remained correlated to basal p85 $\alpha$ PI3K mRNA $(R=0.76, P=0 \cdot 018)$ and basal HKII mRNA $(R=0 \cdot 86, P=0 \cdot 003)$, and was correlated with percentage increase in insulin during the clamp $(R=0 \cdot 73$,
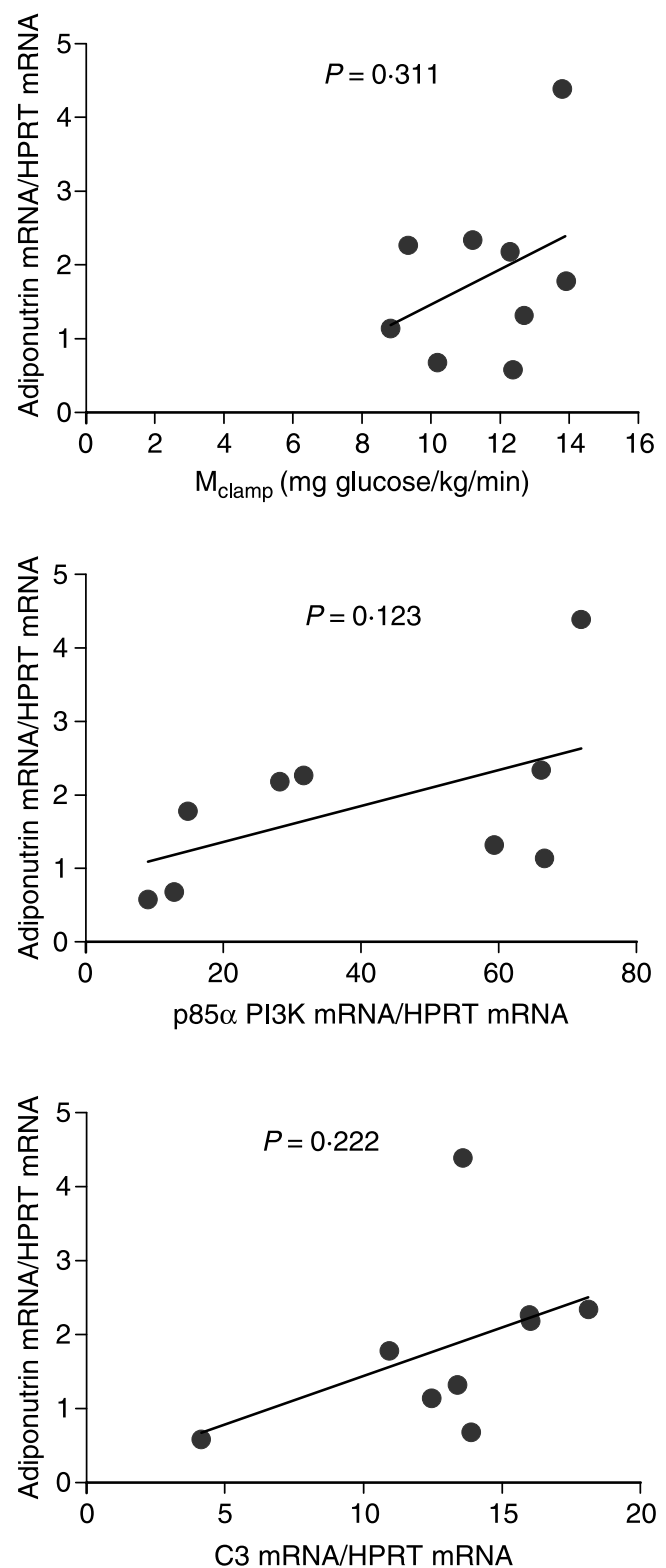

Figure 3 Pearson correlation of adiponutrin with insulin sensitivity and WAT-derived proteins at the insulin-stimulated state induced by HIEG clamps in healthy, lean young men.

$P=0 \cdot 040)$. The correlation of adiponutrin expression with the examined WAT-derived proteins in the insulin-stimulated state is presented in Fig. 3. Insulin-stimulated adiponutrin mRNA levels correlated with those of HKII $(R=0 \cdot 82$, $P=0 \cdot 007)$, leptin $(R=0 \cdot 84, P=0 \cdot 005)$, and adiponectin $(R=0 \cdot 85, P=0 \cdot 004$; Fig. 3). Insulin sensitivity measured by the clamp $\left(M_{\text {clamp }}\right)$ did not correlate with any measured WATderived proteins, including adiponutrin, HKII, and $\mathrm{p} 85 \alpha$ PI3K mRNA. Of note, despite high correlation of HKII and p $85 \alpha$ PI3K mRNA at baseline, their mRNA expression levels were not correlated in the insulin-stimulated state.
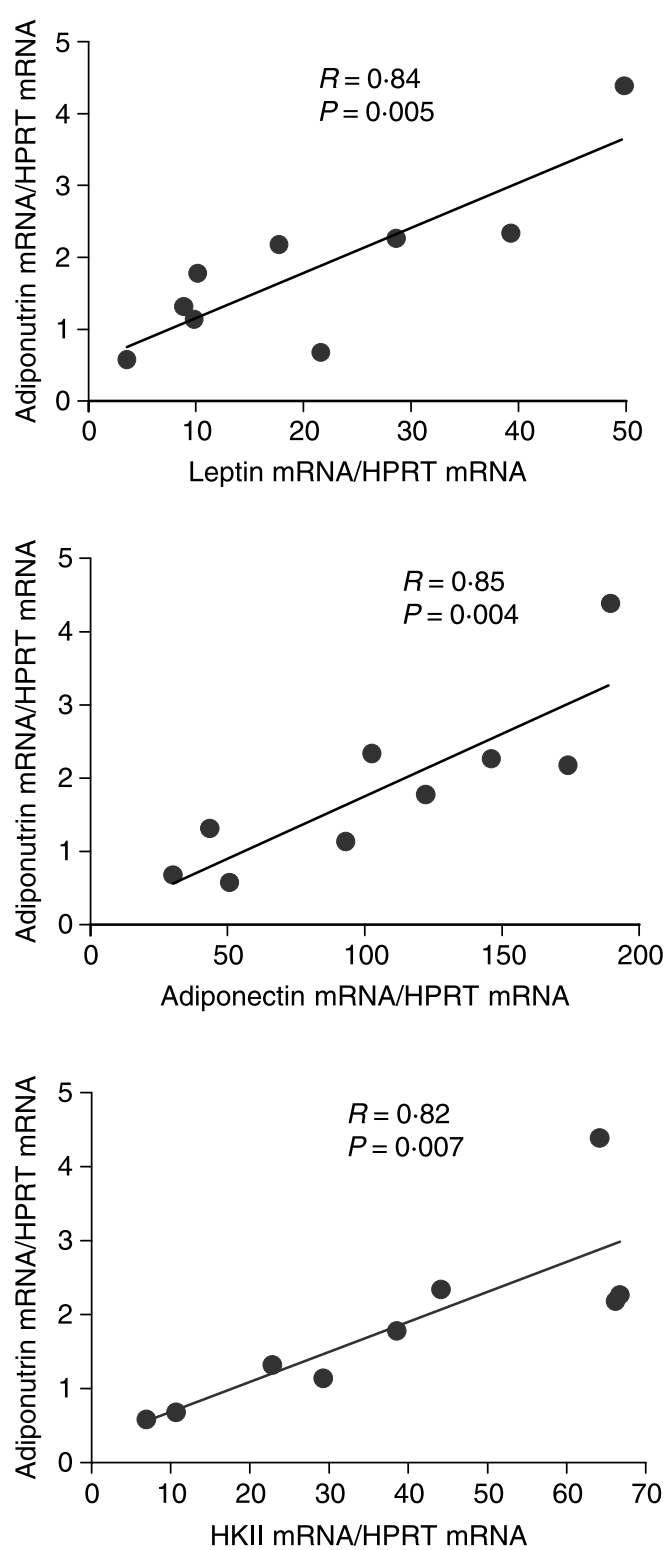


\section{Discussion}

Recent findings by our group and others indicate that, despite being a WAT-derived protein, adiponutrin expression is not elevated in obese subjects (Liu et al. 2004, Moldes et al. 2006). Furthermore, fasting adiponutrin expression as well as insulin-stimulated increase in adiponutrin expression were reduced in obese type 2 diabetic subjects when compared with controls (Moldes et al. 2006). Therefore, the regulation of adiponutrin expression in human may be altered by reduced insulin sensitivity and altered regulation of WATderived proteins in relation to insulin signaling and action in states like type 2 diabetes. In this study, we examined the association of adiponutrin with insulin sensitivity and insulinrelated WAT-derived proteins in both the basal and the insulin-stimulated states in healthy subjects to bypass the confounding effect of obesity and diabetes on the regulation of these WAT-derived proteins, including adiponutrin (Lefai et al. 2001, Johansson et al. 2006, Moldes et al. 2006).

The major findings of this study in healthy young men are that: (1) fasting adiponutrin expression level is correlated with that of p85 $\alpha$ PI3K and HKII, and with serum leptin; (2) acute hyperinsulinemia simultaneously induces mRNA levels of adiponutrin, HKII, and PI3K, increases leptin concentration, and decreases adiponectin concentration; (3) insulin-stimulated adiponutrin expression is highly correlated to that of insulin-stimulated HKII, adiponectin, and leptin.

Novel findings in our study indicate that $3 \mathrm{~h}$ infusion of physiological doses of insulin induced an eightfold increase in adiponutrin expression, which was correlated to the percentage increase in insulin concentrations. Moreover, basal adiponutrin mRNA levels were highly correlated with those of $\mathrm{p} 85 \alpha$ PI3K. PI3K has a pivotal role in the propagation of insulin signaling (Saltiel \& Kahn 2001) and the regulatory subunit $\mathrm{p} 85 \alpha$ examined in this study is the most abundant variant of the regulatory subunits of PI3K in human WAT (Lefai et al. 2001). Many genes involved in the insulin signaling and action are under the PI3K pathway, among which HKII is examined here (Pendergrass et al. 1998). In our study, adiponutrin expression profile mirrored that of HKII. Both adiponutrin and HKII expression levels were: (1) highly correlated to each other and to p85 $\alpha$ PI3K in the basal state, (2) induced by insulin infusion, and (3) highly correlated in the insulin-stimulated state. Therefore, we hypothesize that, like HKII, insulin-stimulation of adiponutrin expression in human WAT may be under the PI3K pathway. Although in our study, adiponutrin expression did not correlate with that of $\mathrm{p} 85 \alpha \mathrm{PI} 3 \mathrm{~K}$ in the insulin-stimulated state, the same observation also applies to HKII, despite the previously documented regulation of HKII expression by the activity of PI3K pathway (Pendergrass et al. 1998).

Type 2 diabetic subjects have reduced insulin action, insulin-mediated upregulation of $\mathrm{p} 85 \alpha$ PI3K in WAT (Ducluzeau et al. 2001), and expression of genes under the PI3K-dependent pathway like HKII (Pendergrass et al. 1998).
Our hypothesis that insulin-mediated regulation of adiponutrin is under the PI3K-dependent pathway may therefore explain reduced adiponutrin expression in type 2 diabetes. However, it should be noted that the lack of correlation between adiponutrin expression and insulin sensitivity at fasting (QUICKI) and insulin-stimulated state $\left(M_{\text {clamp }}\right)$, does not oppose our belief that the degree of insulin resistance may modulate adiponutrin expression. In the present study, the narrow ranges of insulin concentrations and sensitivity in our homogenous and healthy population may have hindered correlation analysis. However, type 2 diabetic subjects exhibit far less insulin sensitivity than our subjects which would drive reduced adiponutrin expression. Of note, the consistent correlation of adiponutrin expression to that of HKII, a major enzyme for the progress of glucose metabolism (Pendergrass et al. 1998) may also suggest that insulin-mediated adiponutrin expression may be glucose-dependent. In fact, this is supported by (1) our data that adiponutrin expression is only reduced in impaired insulin-sensitive and hyperglycemic (or glucose intolerant) type 2 diabetic subjects and not obese subjects (Moldes et al. 2006) and (2) in vitro findings in human adipocytes where insulin failed to induce adiponutrin expression at sub-physiological glucose concentrations $(1 \mathrm{mM})$ as it did at physiological or supra-physiological concentrations of glucose (5 and $25 \mathrm{mM}$; Johansson et al. 2006). Therefore, insulin and glucose are both important regulators of adiponutrin expression.

Another novel finding in our study is that adiponutrin expression was correlated with leptin concentration and expression at the basal and the insulin-stimulated states respectively. Leptin is a WAT-derived factor that is documented to increase insulin sensitivity by various mechanisms in central and peripheral tissues (Faraj et al. 2004). Therefore, leptin pathway may either facilitate insulin regulation of adiponutrin or be directly involved in adiponutrin regulation. Supporting the later mechanism is the finding that adiponutrin expression is reduced in WAT of $o b / o b$ mice, deficient for leptin gene (Lake et al. 2005), while is increased in $f a / f a$ rats (Baulande et al. 2001), deficient for leptin receptor not leptin gene which is in fact increased in these rats (Guerre-Millo 1997). Despite hyperleptinemia in type 2 diabetes, leptin resistance is suggested to be a defect in these subjects (Zimmet et al. 1999). Accordingly, leptin resistance in type 2 diabetic would further explain our observation of a defective adiponutrin expression in these subjects (Moldes et al. 2006).

Similar to leptin, adiponectin increases the insulin sensitivity in peripheral tissue (Faraj et al. 2004). However, adiponectin is the only known WAT-derived protein whose expression and plasma concentration are consistently reduced in both murine and human obesity (Scherer et al. 1995, Arita et al. 1999, Statnick et al. 2000). Furthermore, in our study, hyperinsulinemia reduced adiponectin concentration as was documented by others ( $\mathrm{Yu}$ et al. 2002). Adiponectin expression and concentration are reduced in obese type 2 diabetic subjects being driven by both their obesity and their 
chronic hyperinsulinemia states (Statnick et al. 2000). Therefore, high correlation of adiponutrin expression with that of adiponectin in the insulin-stimulated states would further predict reduced adiponutrin expression in obese type 2 diabetic subjects.

Adiponutrin mRNA levels in our study did not correlate with ASP concentrations or the expression of its precursor protein C3. Moreover, in contrast to adiponutrin, hyperinsulinemia did not affect ASP concentration or C3 expression in our study as was previously reported for C3 (Koistinen et al. 2001). Although ASP concentration and C3 expression are elevated in obese type 2 diabetic subjects (Koistinen et al. 2001, Yang et al. 2005), this was linked to their obesity rather than their insulin resistance in one study (Koistinen et al. 2001). Therefore, adiponutrin and ASP may be differently regulated in human. In fact, the production of ASP from human abdominal WAT increases with ingestion of a high-fat meal (Saleh et al. 1998) and chylomicrons are the most potent regulators of ASP production from human adipocytes (Maslowska et al. 1997, Scantlebury et al. 1998, 2001). On the contrary, adiponutrin expression in mice WAT is neither stimulated with high-fat meal (Polson \& Thompson 2004) nor affected by treatments of cultured human adipocytes with fatty acids (Johansson et al. 2006). Therefore, ASP pathway and its regulators (lipid-related signals) are unlikely to contribute to the regulation of adiponutrin in human (Liu et al. 2004).

In conclusion, adiponutrin expression in s.c. WAT of healthy, lean young men is strongly induced by acute hyperinsulinemia and is highly related to the expression levels of HKII and $\mathrm{p} 85 \alpha$ PI3K. We hypothesize that like HKII, insulin-mediated regulation of adiponutrin expression in human WAT may be through a PI3K-dependent pathway. Accordingly, we believe that our recent finding of reduced adiponutrin expression in obese type 2 diabetic subjects may be driven by reduced insulin sensitivity, defective insulin-mediated regulation of PI3K pathway, and glucose metabolism (implying defective regulation of genes under the PI3K pathway like HKII), as well as an impaired leptin sensitivity and adiponectin expression in these subjects.

\section{Acknowledgements}

This study was funded by a grant from the Canadian Institute for Health Research to R R L (grant no. OHP-65393) and K C (grant no. OOP-69600). M F is supported by post-doctorate fellowship from CIHR and R R L by a fellowship from the Fonds de Recherche en santé du Québec (FRSQ). M M was supported by the Association pour la Recherche sur le Cancer (ARC) and an INSERM fellowship. $\mathrm{K} \mathrm{C}$ is a research scholar of the FRSQ and holds a senior Canada Research Chair in Adipose Tissue. We acknowledge the help of David H St Pierre for technical assistance in the measurement of plasma leptin. The authors declare that there is no conflict of interest that would prejudice the impartiality of this scientific work.

\section{References}

Arita Y, Kihara S, Ouchi N, Takahashi M, Maeda K, Miyagawa J, Hotta K, Shimomura I, Nakamura T, Miyaoka K et al. 1999 Paradoxical decrease of an adipose-specific protein, adiponectin, in obesity. Biochemical and Biophysical Research Communications 257 79-83.

Baulande S, Lasnier F, Lucas M \& Pairault J 2001 Adiponutrin, a transmembrane protein corresponding to a novel dietary- and obesitylinked mRNA specifically expressed in the adipose lineage. Journal of Biological Chemistry 276 33336-33344.

Bertile F \& Raclot T 2004 Differences in mRNA expression of adipocytederived factors in response to fasting, refeeding and leptin. Biochimica et Biophysica Acta 1683 101-109.

DeFronzo RA, Tobin JD \& Andres R 1979 Glucose clamp technique: a method for quantifying insulin secretion and resistance. American Journal of Physiology - Endocrinology and Metabolism 237 E214-E223.

Ducluzeau PH, Perretti N, Laville M, Andreelli F, Vega N, Riou JP \& Vidal H 2001 Regulation by insulin of gene expression in human skeletal muscle and adipose tissue: evidence for specific defects in type 2 diabetes. Diabetes 50 1134-1142

Dusserre E, Moulin P \& Vidal H 2000 Differences in mRNA expression of the proteins secreted by the adipocytes in human subcutaneous and visceral adipose tissues. Biochimica et Biophysica Acta (BBA) - Molecular Basis of Disease 1500 88-96.

English PJ, Coughlin SR, Hayden K, Malik IA \& Wilding JPH 2003 Plasma adiponectin increases postprandially in obese, but not in lean, subjects. Obesity Research 11 839-844.

Faraj M, Lu HL \& Cianflone K 2004 Diabetes, lipids, and adipocyte secretagogues. Biochemistry and Cell Biology 82 170-190.

Guerre-Millo M 1997 Regulation of $o b$ gene and overexpression in obesity. Biomedecine and Pharmacotherapy 51 318-323.

Jenkins CM, Mancuso DJ, Yan W, Sims HF, Gibson B \& Gross RW 2004 Identification, cloning, expression and purification of three novel human calcium independent phospholipase $\mathrm{A}_{2}$ family members possessing triacylglycerol lipase and acylglycerol transacylase activities. Journal of Biological Chemistry 279 48968-48975.

Johansson LE, Hoffstedt J, Parikh H, Carlsson E, Wabitsch M, Bondeson AG, Hedenbro J, Tornqvist H, Groop L \& Ridderstrale M 2006 Variation in the adiponutrin gene influences its expression and associates with obesity. Diabetes 55 826-833.

Karelis AD, Faraj M, Bastard JP, St Pierre DH, Brochu M, Prud'homme D \& Rabasa-Lhoret R 2005 The metabolically healthy, but obese individual presents a favorable inflammation profile. Journal of Clinical Endocrinology Metabolism 90 4145-4150.

Kershaw EE, Hamm JK, Verhagen LAW, Peroni O, Katic M \& Flier JS 2006 Adipose triglyceride lipase: function, regulation by insulin, and comparison with adiponutrin. Diabetes 55 148-157.

Koistinen HA, Vidal H, Karonen SL, Dusserre E, Vallier P \& Koivisto VA 2001 Plasma acylation stimulating protein concentration and subcutaneous adipose tissue $\mathrm{C} 3 \mathrm{mRNA}$ expression in nondiabetic and type 2 diabetic men. Arteriosclerosis Thrombosis and Vascular Biology 21 1034-1039.

Lake AC, Sun Y, Li JL, Kim JE, Johnson JW, Li D, Revett T, Shih HH, Liu W, Paulsen JE et al. 2005 Expression, regulation, and triglyceride hydrolase activity of adiponutrin family members. Journal of Lipid Research $\mathbf{4 6}$ 2477-2487.

Lefai E, Roques M, Vega N, Laville M \& Vidal H 2001 Expression of the splice variants of the p85alpha regulatory subunit of phosphoinositide 3-kinase in muscle and adipose tissue of healthy subjects and type 2 diabetic patients. Biochemical Journal 360 117-126.

Liu YM, Moldes M, Bastard JP, Bruckert E, Viguerie N, Hainque B, Basdevant A, Langin D, Pairault J \& Clement K 2004 Adiponutrin: a new gene regulated by energy balance in human adipose tissue. Journal of Clinical Endocrinology and Metabolism 89 2684-2689.

Maslowska M, Scantlebury T, Germinario R \& Cianflone K 1997 Acute in vitro production of ASP in differentiated adipocytes. Journal of Lipid Research 38 21-31. 
Maslowska M, Vu H, Phelis S, Sniderman AD, Rhode BM, Blank D \& Cianflone K 1999 Plasma acylation stimulating protein, adipsin and lipids in non-obese and obese populations. European Journal of Clinical Investigation 29 679-686.

Moldes M, Beauregard G, Faraj M, Peretti N, Ducluzeau PH, Laville M, Rabasa-Lhoret R, Vidal H \& Clément K 2006 Adiponutrin gene is regulated by insulin and glucose in human adipose tissue. European Journal of Endocrinology 155 461-468.

Pagana KD \& Pagana TJ 1997 Diagnostic and Laboratory Test Reference. edn 3, Missouri, USA: Mosby-Year Book, Inc.

Pendergrass M, Koval J, Vogt C, Yki-Jarvinen H, Iozzo P, Pipek R, Ardehali H, Printz R, Granner D, DeFronzo RA et al. 1998 Insulin-induced hexokinase II expression is reduced in obesity and NIDDM. Diabetes 47 387-394.

Polson DA \& Thompson MP 2003 Adiponutrin mRNA expression in white adipose tissue is rapidly induced by meal-feeding a high-sucrose diet. Biochemical and Biophysical Research Communications 301 261-266.

Polson DA \& Thompson MP 2004 Macronutrient composition of the diet differentially affects leptin and adiponutrin mRNA expression in response to meal feeding. Journal of Nutritional Biochemistry 15 242-246.

Rabasa-Lhoret R, Bastard JP, Jan V, Ducluzeau PH, Andreelli F, Guebre F, Bruzeau J, Louche-Pellissier C, MaItrepierre C, Peyrat J et al. 2003 Modified quantitative insulin sensitivity check index is better correlated to hyperinsulinemic glucose clamp than other fasting-based index of insulin sensitivity in different insulin-resistant states. Journal of Clinical Endocrinology Metabolism 88 4917-4923.

Saleh J, Summers LKM, Cianflone K, Fielding BA, Sniderman AD \& Frayn KN 1998 Coordinated release of acylation stimulating protein (ASP) and triacylglycerol clearance by human adipose tissue in vivo in the postprandial period. Journal of Lipid Research 39 884-891.

Saltiel AR \& Kahn R 2001 Insulin signalling and the regulation of glucose and lipid metabolism. Nature 414 799-806.

Scantlebury T, Maslowska M \& Cianflone K 1998 Chylomicron specific enhancement of acylation stimulating protein (ASP) and precursor protein C3 production in differentiated human adipocytes. Journal of Biological Chemistry 273 20903-20909.

Scantlebury T, Sniderman AD \& Cianflone K 2001 Retinoic acid regulation of acylation stimulating protein (ASP) and complement C3 in human adipocytes. Biochemistry Journal 356 445-452.
Scherer PE, Williams S, Fogliano M, Baldini G \& Lodish HF 1995 A novel serum protein similar to $\mathrm{C} 1 \mathrm{q}$, produced exclusively in adipocytes. Journal of Biological Chemistry 270 26746-26749.

Statnick MA, Beavers LS, Conner LJ, Corominola H, Johnson D, Hammond CD, Rafaeloff-Phail R, Seng T, Suter TM, Sluka JP et al. 2000 Decreased expression of apM1 in omental and subcutaneous adipose tissue of humans with type 2 diabetes. International Journal of Experimental Diabetes Research 1 81-88.

Tan GD, Debard C, Funahashi T, Humphreys SM, Matsuzawa Y, Frayn KN, Karpe F \& Vidal H 2005 Changes in adiponectin receptor expression in muscle and adipose tissue of type 2 diabetic patients during rosiglitazone therapy. Diabetologia 48 1585-1589.

Vidal H, Auboeuf D, De Vos P, Staels B, Riou JP, Auwerx J \& Laville M 1996 The expression of $o b$ gene is not acutely regulated by insulin and fasting in human abdominal subcutaneous adipose tissue. Journal of Clinical Investigation 98 251-255.

Wiesner G, Morash BA, Ur E \& Wilkinson M 2004 Food restriction regulates adipose-specific cytokines in pituitary gland but not in hypothalamus. Journal of Endocrinology $180 \mathrm{R} 1-\mathrm{R} 6$.

Yang Y, Lu HL, Zhang J, Yu HY, Wang HW, Zhang MX \& Cianflone K 2005 Relationships among acylation stimulating protein, adiponectin and complement C3 in lean vs obese type 2 diabetes. International Journal of Obesity 30 439-446.

Yu JG, Javorschi S, Hevener AL, Kruszynska YT, Norman RA, Sinha M \& Olefsky JM 2002 The effect of thiazolidinediones on plasma adiponectin levels in normal, obese, and type 2 diabetic subjects. Diabetes 51 2968-2974.

Zimmet P, Boyko EJ, Collier GR \& de Courten M 1999 Etiology of the metabolic syndrome: potential role of insulin resistance, leptin resistance, and other players. Annals of the New York Academy of Sciences $89225-44$

Received in final form 26 July 2006

Accepted 15 August 2006

Made available online as an Accepted Preprint 25 August 2006 